\title{
The effect of light intensity on some morphological and physiological aspects of the crop perennial ryegrass (Lolium perenne L. var. 'Cropper') and its effect on seed production
}

\author{
J. H. J. Spiertz and J. Ellen
}

Received: 30 June 1972

Department of Field Crops and Grassland Husbandry of the Agricultural University, Wageningen, the Netherlands

\section{Summary}

In 1968 and 1969 the effect of light intensity on the seed production of perennial ryegrass was studied in a field trial. To this purpose light levels were applied by additional light of high-pressure mercury lamps and shading with polyethylene netting; both treatments without changing the natural photoperiod. In the 1968 trial the light levels were applied in spring and in the 1969 trial in the preceding autumm.

The increased light intensity considerably stimulated tillering in autumn as well as in spring, whereas the number of tillers decreased under reduced light intensity. The difference in tiller number occurring in autumn levelled down during winter and in early spring, the effect of light intensity in spring being expressed in the number of vegetative and reproductive tillers. This also applies to the individual tiller weight which increased with increasing visible radiation.

The light treatment in spring induced a great variation in ear-bearing tillers. The seed yield was found to be closely correlated $(r=0.95)$ to the number of reproductive tillers, to a less extent $(r=0.50)$ to the number of seeds per ear and hardly at all $(r=-0.16)$ to the individual seed weight. The light treatment in autumn induced a slight variation in number of reproductive tillers, but the fertility of the inflorescences differed; under these conditions the number of seeds per ear was more important in the seed yield than the number of reproductive tillers. Light intensity also affected the plant habit and with it to a great extent, the green-leaf area of the crop. For the topmost 3 leaves and internodes and ear the maximum value of the area index in the additional light, the sunshine and the shaded treatments were 13.2, 11.6 and 7.7, respectively. Compared to other seed-producing crops, such as cereals, these are very high values. Despite this dense stand with considerable mutual shading, the supply of water-soluble carbohydrates in the reproductive tillers increased exponentially until ripening, after which it dropped sharply.

The results suggest that selection for shortness and firmness of the reproductive tillers may have a favourable effect on seed production.

\section{Introduction}

An important feature of seed growing is grasses in the comparatively low seed yield with respect to the total dry matter produced. This is due to the properties of these perennial plants to control their persistency and propagation vegetatively rather than reproductively. 
The selection for the greatest possible production of vegetative plant parts for roughage and that for long persistence of the plants have the same object in view. In addition the requirements of a firm and short turf for lawns and sport field grasses, in which stem formation is considered an undesired character, lead to a selection not favouring seed production.

Despite the genetic properties in the cultivated grasses not favouring seed formation, the best possible seed production is necessary, since a considerable amount of seed is required in the seeding of grassland, lawns, sport fields, etc. Improved seed production can be attained as follows:

a. selection also favouring properties contributing to better seed formation;

b. seed growing under optimum conditions for reproductive development of the crop.

This paper only deals with the second aspect and especially the effect of light on a number of crop physiological and morphological factors affecting the seed yield, such as total dry-matter production, dry-matter distribution, tillering and fertility of the tillers, morphological structure of the crop and the formation of reserves in the above-ground parts of the plant.

The effect of light intensity was studied by additional illumination and shading in the field. This was done in a spring treatment in 1968 and in the harvest year 1969 the effect was determined of an autumn treatment in the preceding year.

\section{Literature}

Shoot formation in perennial grasses can take place continuously. Shoots vernalized, according to Langer and Lambert (1959), have an annual or biennial life cycle. Flower induction in Lolium perenne will occur under short-day conditions as well as at low temperatures (Cooper, 1960). In the field this means that the shoots formed in autumn receive a cold treatment during winter and that the shoots formed in spring are partly brought to flower initiation by short day. Flower induction, for that matter, can apparently be transferred to some extent from vernalized to non-vernalized shoots (Evans and Wardlaw, 1964). This makes it possible that even low tillering plants in autumn, may have more fertile tillers than vernalized shoots per plant in spring.

Schöberlein's investigations (1966) showed that autumn tillers with at least 4 leaves before winter, have the best seed producing inflorescences next year. Fertility of the tillers decreases as they are formed later. Similar characteristics were found by Langer and Lambert (1959) in meadow fescue. The cutting or grazing of tillers in autumn does not affect the percentage of fertile tillers, provided nitrogen application is adjusted; however, ear initiation tends to be somewhat later (Roberts, 1965). Apparently the ontogenetic age of the tiller before winter is more important in the differentiation of the growing point than the area of green leaves present.

Shoot formation in spring, vegetative as well as reproductive, is mainly dependent on the nitrogen application, weather and variety characters. High nitrogen application stimulates tillering and leaf formation, in which the positive affect of nitrogen on tillering is stimulated by additional light (Langer, 1966). This is caused by the greater availability of carbohydrates as an energy source for the young tillers. There also are varietal and type differences; pasture types, for instance, will form more tillers than hayfield types and the tetraploid varieties have a smaller number of tillers than diploid varieties (van der Meer, 1969).

The position of the individual tiller on the plant is also important, since the primary 
tillers are found to be more fertile than tillers of a higher order. The chances of initiation decrease, as the relevant tiller is formed at a later moment. This probably is the reason for autumn and early spring fertilizer applications stimulating the number of ear-bearing tillers and late nitrogen applications only stimulating vegetative tiller formation (Anslow, 1962).

With respect to the effect of light on the development of the inflorescence little is known up till now. In timothy the number of spikelets on the main axis decreased with $30 \%$ due to a light reduction of $70 \%$ in May (Ryle, 1961). In other grasses the effect of light reduction on inflorescence size was not as clear, except for light levels below $25 \%$ of normal sunshine.

The factor light is mainly active through tillering on the number of reproductive shoots and to a less extent through fertility of the inflorescences. The main shoot in a shading experiment was always found to be $100 \%$ fertile, fertility of the side-shoots depending on the light intensity and varying from 19 to $54 \%$ (Ryle, 1967). In general, shading was found to retard the reproductive phase, decrease the number of reproductive shoots and affect to a small extent ear size (Kleinendorst and Sonneveld, 1965).

In perennial ryegrass, unlike in other grasses, a dense stand did not have an adverse effect on the seed yield per area unit. Fertility of the individual shoots probably is affected; thus Ryle (1964) found in individual plants of S24, 275 spikelets per ear, whereas Anslow (1963) determined an average spikelet number of 104 per ear in a crop. The considerable mutual shading at high densities does not inhibit ear initiation in perennial ryegrass, but reduces potential fertility of the ears.

Mutual shading of tillers mainly depends on the size of the leaf area (Koblet et al., 1969). The LAI values in grass are much higher than in most other crops: Donald and Black (1958) and Brougham (1958) gave values of 9 and 11, respectively. Hryncewicz's investigations (1967) with 26 varieties of perennial ryegrass showed that the leaf area per shoot at heading varied in the very early varieties from $27 \mathrm{~cm}^{2}$ (dipliod) to $44-57 \mathrm{~cm}^{2}$ (both tetraploid), in the mid-early varieties from $39-46 \mathrm{~cm}^{2}$ and in the late varieties from $25-38 \mathrm{~cm}^{2}$. Unfortunately, in this paper the number of reproductive shoots present is not mentioned. Assuming that in the tetraploid varieties this averaged 15 and in the diploid 25, here too a LAI value was attained of 8 to 10 . Per reproductive shoot there were at the moment of heading 3 to 4 green leaves.

The physiological function of the top leaves greatly corresponds with that of the leaves of a wheat plant; of the assimilates formed in the flag leaf $55-75 \%$ was translocated to the ear after heading (Ryle, 1970). However, there was no indication which part of this contribution of the flag leaf formed in the total dry-matter increase in the ear. In the reproductive shoot the stem is a larger sink of assimilates than the ear in perennial ryegrass.

\section{Material and methods}

The trial with additional light in spring (1968) was done on a strip of sandy soil with a high humus content. On 7 September 1967 an early hay type of perennial ryegrass, variety 'Cropper', was sown at $9 \mathrm{~kg}$ viable seed per ha. As an autumn fertilization $200 \mathrm{~kg}$ nitrate of lime ( $=32 \mathrm{~kg} \mathrm{~N})$ per ha was applied, whereas the potassium and phosphorus fertilizers were applied on 19 February $1968,400 \mathrm{~kg} \mathrm{k}-40\left(=160 \mathrm{~kg} \mathrm{~K}_{2} \mathrm{O}\right)$ and $500 \mathrm{~kg}$ superphosphate $\left(=95 \mathrm{~kg} \mathrm{P}_{2} \mathrm{O}_{5}\right)$ per ha. The treatments in spring in the period from 1 April to 30 June were: 
A. light intensity

1. sunshine + additional light $(\mathrm{H})$ : average $188 \mathrm{cal} \mathrm{cm}^{-2} \mathrm{day}^{-1}$

2. sunshine $(\mathrm{N})$ : average $140 \mathrm{cal} \mathrm{cm}^{-2} \mathrm{day}^{-1}$

3. shading (L): average $84 \mathrm{cal} \mathrm{cm}^{-2} \mathrm{day}^{-1}$

(wavelength $400-700 \mathrm{~nm}$ )

\section{$B$. nitrogen levels}

1. high level ( $\mathrm{kg} \mathrm{N} / \mathrm{ha})$

$\begin{array}{rrr}\text { H } & \text { N } & \text { L } \\ 250 & 200 & 150 \\ 200 & 150 & 100\end{array}$

2. low level (kg N/ha)

This resulted in 6 treatments with 4 replicates each. The additional light and shading was started at the stage of ear initiation (about 3 April). The additional light with 8 highpressure mercury lamps (HPL-R) of $400 \mathrm{~W}$ per $7 \mathrm{~m}^{2}$ soil surface at a height of $50 \mathrm{~cm}$ above the crop during 14 hours gave an additional light intensity of $48 \mathrm{cal} \mathrm{cm}^{-2} \mathrm{day}^{-1}$ of visible light. The polyethylene netting reduced the light intensity to $60 \%$ of the incoming radiation. As was already mentioned with the treatments, the nitrogen dressings were adjusted to the dry-matter production to be expected per light level.

For the crop analysis plant and tiller countings were carried out on 26 September and 4 December 1968, and on 11 March, 1 and 2 April, 10 and 28 May, 10 and 25 June, $0.25 \mathrm{~m}^{2}$ per plot were harvested intermediately. The number of tillers in these samples was counted, the dry-matter weight of above-ground parts, stubbles and roots determined, nitrogen content (Kjeldahl) and water-soluble carbohydrates (van der Plank) analysed. To estimate the green leaf area lenghts of leaves, internodes and ear were measured. The area indices were determined in the following way:

of the leaf: lenght $X$ average width $X$ number of reproductive tillers per $\mathrm{m}^{2}$ (one-sided); of the internode: length $\times$ diameter $\times 1 / 2 \times$ number of reproductive tillers per $\mathrm{m}^{2}$ (onesided);

of the ear: length $\times$ average width $\times 2 \times$ number of reproductive tillers per $\mathrm{m}^{2}$ (twosided).

At the ultimate harvest there was an area of $3 \mathrm{~m}^{2}$, which, to prevent harvest losses, were harvested in two parts at different times. Dependent on the ripening stage of the $\mathrm{H}, \mathrm{N}, \mathrm{L}$ treatments, they were harvested on 20 and 27 June, 27 June and $3 \mathrm{July,} 3$ and $10 \mathrm{July}$, respectively. After the ultimate harvest the fresh material was dried at $30^{\circ} \mathrm{C}$ and threshed with a special thresher. The percentage of clean seed, 1000-grain weight and germination were determined by the standard procedure of the Seed Testing Station at Wageningen.

The trial (1969) with light levels in autumn was done with the same crop as the preceding trial. The crop was sown on 24 July 1968, again at a rate of $15 \mathrm{~kg}$ seed per ha. After sowing $200 \mathrm{~kg}$ NPK fertilizer (14-14-14) per ha were applied. After cutting on 1 October 1968 supplementary nitrogen at $30 \mathrm{~kg} \mathrm{~N}$ per ha was applied. The spring dressing was $100 \mathrm{~kg} \mathrm{P} \mathrm{P}_{2}$ ser ha, $160 \mathrm{~kg} \mathrm{~K}{ }_{2} \mathrm{O}$ per ha and $250 \mathrm{~kg} \mathrm{~N}$ per ha. The phosphate and potassium fertilizers were applied on 6 February and the nitrogen on 28 February 1969.

The light treatments were as follows:

$$
26 /-1 / 10
$$

$$
1 / 10-29 / 10
$$

1. sunshine + additional light $(\mathrm{H})$ av. 174

2. sunshine (N) av. 86

3. shading

(L) av. 52

$$
\begin{aligned}
& \text { av. } 106 \mathrm{cal} \mathrm{cm}^{-2} \text { day }^{-1} \\
& \text { av. } 43 \mathrm{cal} \mathrm{cm}^{-2} \text { day }^{-1} \\
& \text { av. } 26 \mathrm{cal} \mathrm{cm}^{-2} \text { dayy-1 }^{-1} \\
& \text { (wavelength } 400-700 \mathrm{~nm} \text { ) }
\end{aligned}
$$

Duration of the supplementary light in the period 26 August to 1 October was 14 hours per day, and from 1 to and including 29 October 10 hours per day. Due to the margin 
effects of the lamps, lengthening of the photoperiod usually attending on additional light was also present in the remaining treatments.

On 4 August the number of plants was counted. Yield determinations and tiller countings were carried out on 1 October in the whole field, on 29 October, 27 November, 7 December in 1968, and on 23 April, 7 May, 21 May, 4 June, 17 June and 2 July 1969 in experimental plots of $1 / 8 \mathrm{~m}^{2}$. The treatment of the harvested material, as a matter of fact, was more limited than that in the preceding experiment.

\section{Results}

\section{Number of vegetative and reproductive shoots}

At the beginning of the spring experiment (September 1967) the number of plants per $\mathrm{m}^{2}$ was 436; this number persisted at the same level during winter, as shown by the number of plants in March, which was 418 per $\mathrm{m}^{2}$. Tillering continued during winter, which is demonstrated by the number of tillers on 4 December 1967 and 11 March 1968 which was 4.8 and 7.1 respectively. Of the tillers present in March $70 \%$ had rooted.

The light level in spring distinctly affected tillering: the light reduction due to shading effected an appreciable decrease in the number of tillers per plant (Fig. 1).

Light intensity also affected the rate of heading; the treatments with additional light headed one week earlier than the sunshine and shaded treatments, 1 and $6 \mathrm{May}$, respectively. The flowering dates were 27 May, 29 May and 4 June, respectively. This variation

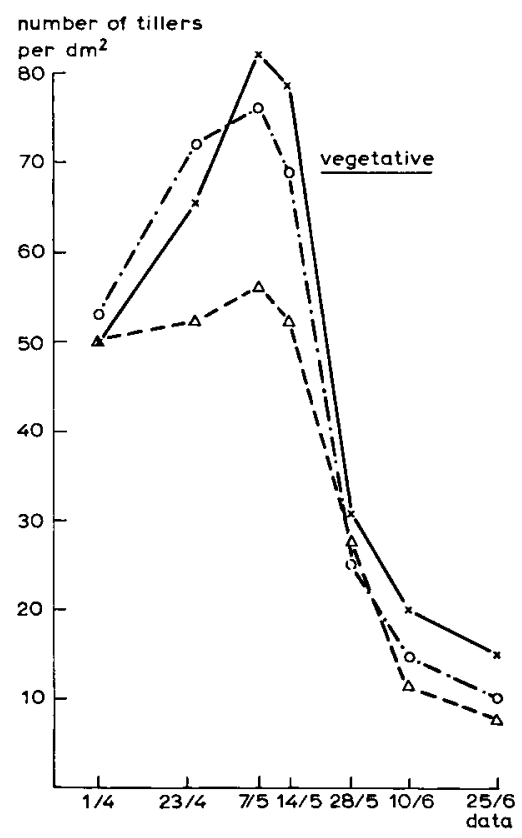

$$
\begin{aligned}
& x-x=\text { sunfight }+H P L \\
& 0--0=\text { suntight } \\
& \Delta--\Delta=\text { shadow }
\end{aligned}
$$

reproductive

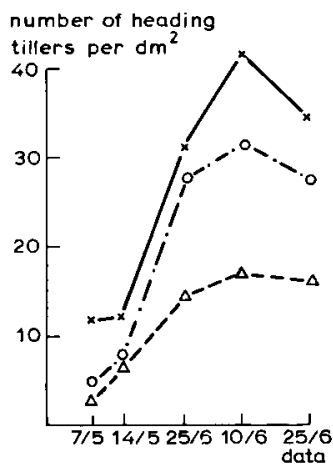

Fig. 1. Trend in number of vegetative and reproductive shoots at three levels of light intensity. 
Table 1. Number of tillers per $\mathrm{dm}^{2}$ at three light levels in autumn and the further trend in the number of vegetative and reproductive tillers.

\begin{tabular}{|c|c|c|c|c|c|c|}
\hline \multirow[t]{2}{*}{ Date } & \multicolumn{4}{|c|}{ Light intensity } & \multirow[t]{2}{*}{ c.v. } & \multirow[t]{2}{*}{ Significance } \\
\hline & $\mathrm{H}$ & $\mathrm{N}$ & $\mathrm{L}$ & mean & & \\
\hline $1-10-' 68$ & 44.9 & 39.1 & 29.8 & 37.9 & - & 一 \\
\hline \multicolumn{7}{|l|}{ after cutting } \\
\hline $29-10-' 68$ & 36.4 & 31.0 & 13.3 & 26.9 & 10.3 & $* * * * *$ \\
\hline 27-11-'68 & 43.0 & 33.7 & 13.1 & 29.9 & 17.8 & $* * * *$ \\
\hline $17-12-68$ & 42.7 & 36.2 & 16.0 & 31.6 & - & - \\
\hline 23- 4-'69 & 80.6 & 69.4 & 57.5 & 69.2 & 17.6 & n.s. \\
\hline 7- 5-'69 & 89.4 & 77.1 & 74.9 & 80.5 & 13.8 & $*$ \\
\hline 21- 5-69 & 65.8 & 70.8 & 69.7 & 68.8 & 13.7 & n.s. \\
\hline 4- 6-'69 & 38.5 & 45.9 & 40.6 & 41.6 & 18.3 & $*$ \\
\hline 17- 6-'69 & 35.4 & 31.9 & 47.0 & 38.1 & 8.6 & $* * * *$ \\
\hline \multicolumn{7}{|c|}{ ultimate harvest } \\
\hline $\begin{array}{l}\text { (reproductive } \\
\text { tillers only) }\end{array}$ & 31.9 & 32.0 & 36.5 & 33.5 & - & - \\
\hline
\end{tabular}

n.s.: $\alpha>0.1 ; *: 0.05<\alpha \leqslant 0.1 ; * * 0.01<\alpha \leqslant 0.05 ; * * *: 0.001<\alpha \leqslant 0.01 ; * * * \alpha \leqslant 0.001$

in development rate probably was caused by small differences in the temperature, which were due to additional heat of the HPL lamps and by reducing the direct sunshine in the shaded treatment.

The formation of fertile tillers, measured by the number of ear-bearing tillers, increased by additional light from 31.7 to 41.8 per $\mathrm{dm}^{2}$ and decreased by shading from 31.7 to 17.3 per $\mathrm{dm}^{2}$. During ripening in all the treatments a number of reproductive tillers died prematurely, especially at very high densities.

In the trial with different light levels in autumn the effect was studied of the morphological and physiological development of tillers in autumn on seed production in the next year.

At the beginning of the autumn experiment the number of plants per $m^{2}$ was 405 (5

Table 2. Tiller weight $(\mathrm{mg})$ in an autumn treatment at three light levels.

\begin{tabular}{lrrr}
\hline Date & H & N & L \\
1-10-'68 & 80 & 67 & 56 \\
after cutting & & & \\
29-10-'68 & 42 & 37 & 25 \\
27-11-'68 & 51 & 51 & 41 \\
17-12-'68 & 53 & 47 & 37 \\
23- 4-'69 & 47 & 26 & 27 \\
8- 5-'69 & 70 & 72 & 50 \\
21- 5-'69* & 212 & 239 & 164 \\
4- 6-'69* & 285 & 244 & 220 \\
2- 7-'69* & 321 & 290 & 275 \\
& & & \\
\hline
\end{tabular}

* Reproductive tillers only. 
August 1968). Additional light and shading onwards 26 August had a slight effect on the number of plants, but affected the number of tillers per plant considerably. In the additional light, sunshine and shading treatments this number on 1 October was $10.4,9.3$ and 7.8 tillers per plant, respectively. The resulting tiller number per $\mathrm{dm}^{2}$ is given in Table 1 .

After cutting the crop (at $5 \mathrm{~cm}$ height) on 1 October, in regrowth it was established that the number of plants per $\mathrm{dm}^{2}$ and the number of tillers per plant were lower as the light intensity was lower.

The considerable differences in tiller number in autumn were soon levelled in spring. Eventually, the shaded treatment even had a somewhat higher tiller number. Tiller weight was however higher in the additional light treatment (Table 2) with respect to the aboveground parts as well as to the roots. This is demonstrated by the shoot/root ratio on 1 October: in the additional light treatment $(\mathrm{H}) 2.0$, in the sunshine treatment $(\mathrm{N}) 2.2$ and in the shaded treatment (L) 2.9. This difference in rooting will also have contributed in the effect of the light treatment in the period 26 August - 29 October on tiller weight continuing right up to the ultimate harvest in the next year.

\section{Fertility of the reproductive tillers}

A counting in the spring trial on 25 June of the unthreshed tillers gave the following data on the three light levels:

Additional light $(\mathrm{H})$ - 92.4 seeds and 18.1 spikelets per ear

Sunshine $\quad$ (N) -92.6 seeds and 16.7 spikelets per ear

Shade $\quad(\mathrm{L})-105.0$ seeds and 17.5 spikelets per ear

The actual number of seeds per ear harvested was however much lower. Seed setting, calculated as the relation between number of florets and number of viable seeds, was taken as a measure for fertility of the tillers. This was in the additional light, sunshine and shaded treatments 35,32 and $27 \%$, respectively. On an average the 5 to 6 spikelets per ear only yielded 1 to 2 viable seeds.

This shows that fertility is not a genetical aspect only, but can be affected considerably by habitat factors, e.g. the effect of high air humidity on flowering (in view of the lodging effect), but also the effect of light intensity on the availability of assimilates for the rapidly growing embryo.

\section{Dry-matter production and distribution}

Striking in growing grass seed crops is that only a small part of the total dry-matter production is destined for the seed. In the spring experiment the seed yield (y), due to the variable light intensity, showed a linear relationship with the above-ground dry-matter production $(x)$, reflected by $y=0.2 x-84(r=0.95)$. Like tillering, the dry-matter production increased with light intensity (Fig. 3A), from the time of stem elongation.

From the end of April there was a significant difference in dry-matter yield between the three light treatments. Maximum yields were obtained in the $\mathrm{H}$ treatment on 10 June, and in the $\mathrm{N}$ and $\mathrm{L}$ treatments on $25 \mathrm{June}$. Of this stage the dry-matter distribution in tiller, stubbles and roots is reflected in Table 3. The shoot/root ratio at the beginning of April was about 2.5 , increased considerably during stem elongation and then attained a constant level at about 6.0. Striking were the slight differences in shoot/root ratio between the three light treatments in this period; which is in disaccordance with the distinct differences in the preceding autumn.

The effect of light intensity on the increase in dry-matter weight is well illustrated by 
Table 3. Dry-matter distribution in the tiller, stubble and root at the stage of maximum dry-matter weights in a spring treatment at three light levels. In brackets percentages of the total.

\begin{tabular}{lrrrr}
\hline & Total dry matter & \multicolumn{2}{l}{ Above-ground } & \multicolumn{2}{l}{ Under-ground } & \\
\cline { 3 - 5 } & & \multicolumn{1}{l}{ tiller } & stubble & \multicolumn{1}{c}{ root } \\
Shade (L) & $8,023(100)$ & $7,025(88)$ & $499(6)$ & $499(6)$ \\
Sunshine (N) & $14,722(100)$ & $12,276(83)$ & $1,672(11)$ & $774(5)$ \\
Sunshine + & $17,922(100)$ & $15,270(85)$ & $1,479(8)$ & $1,172(7)$ \\
HPL(H) & & & & \\
\hline
\end{tabular}

the growth rate. In the period of heading until flowering this averaged in the $\mathrm{H}, \mathrm{N}$ and $\mathrm{L}$ treatments 289,228 and $133 \mathrm{~kg} \mathrm{ha}^{-1} \mathrm{day}^{-1}$, respectively.

The light levels applied in autumn had a considerable effect on the dry-matter production. On 27 November the dry-matter weight of the $\mathrm{H}, \mathrm{N}$ and $\mathrm{L}$ treatments was 2200,1700 and $600 \mathrm{~kg} \mathrm{ha}^{-1}$, respectively. However, in spring a considerable levelling occurred and at the beginning of June, there were no significant differences left.

\section{Seed yield and yield components}

In the spring treatment the effect of light intensity on seed yield was mainly effected through the number of ear-bearing tillers. This number was closely correlated to the seed yield (Fig. 2). Striking was the slight effect of radiation on seed setting at the low nitrogen level, whereas at the high nitrogen level the number of seeds per ear dropped sharply at the lower light levels (Table 4). This negative effect was caused by lodging starting earlier due to $50 \mathrm{~kg}$ extra nitrogen per ha. In the 'L-150' treatment lodging was already observed on 24 April, 'N-200' following in the second week of May. The 1000-grain weight was highest in the 'sunshine' treatments, with a slight decrease in the 'shaded' as well as in the

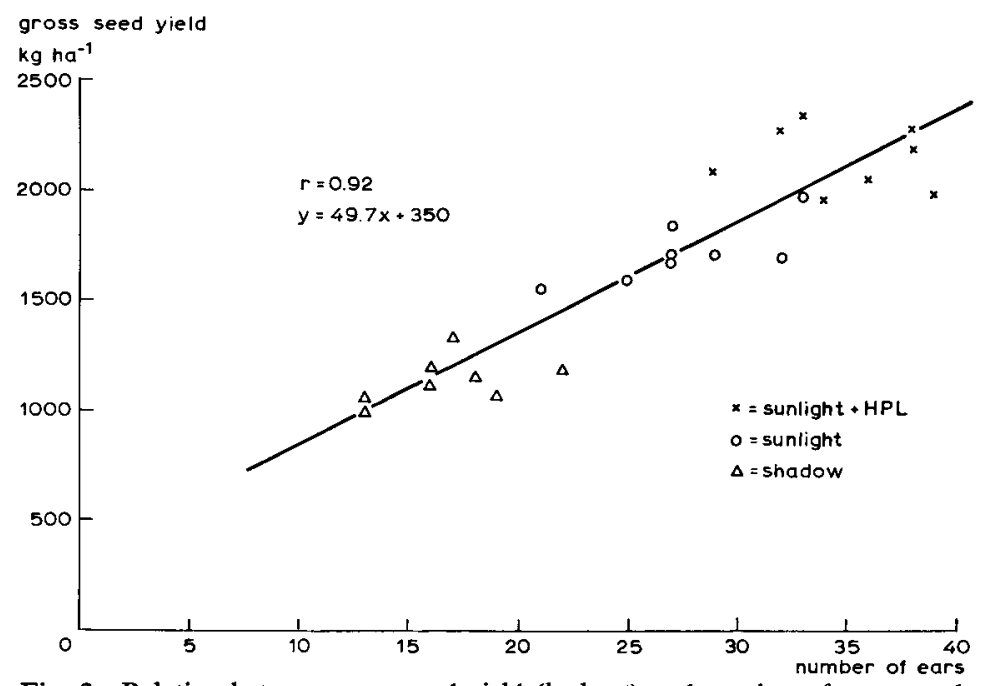

Fig. 2. Relation between gross seed yield $\left(\mathrm{kg} \mathrm{ha}^{-1}\right)$ and number of ears per $\mathrm{dm}^{2}$.

Neth. J. agric. Sci. 20 (1972) 
Table 4. Seed yield and yield components in the spring trial (1968).

\begin{tabular}{|c|c|c|c|c|c|c|c|c|}
\hline $\begin{array}{l}\text { Treat- } \\
\text { ments }\end{array}$ & $\begin{array}{l}\text { Gross } \\
\text { seed } \\
\text { yield } \\
(\mathrm{kg} \mathrm{ha-1)}\end{array}$ & $\begin{array}{l}\text { Cleaned } \\
\text { seed }(\%)\end{array}$ & $\begin{array}{l}\text { Germi- } \\
\text { nation } \\
(\%)\end{array}$ & $\begin{array}{l}\text { Clean } \\
\text { and } \\
\text { viable } \\
\text { seed } \\
(\mathrm{kg} \mathrm{ha-1)}\end{array}$ & $\begin{array}{l}\text { Number } \\
\text { of ears } \\
\text { per } \mathrm{dm}^{2}\end{array}$ & $\begin{array}{l}\text { Number } \\
\text { of seeds } \\
\text { per ear }\end{array}$ & $\begin{array}{l}1,000- \\
\text { seed } \\
\text { weight } \\
\text { (g) }\end{array}$ & $\begin{array}{l}\text { Calcu- } \\
\text { lated net } \\
\text { seed } \\
\text { yield } \\
(\mathrm{kg} \mathrm{ha-1)}\end{array}$ \\
\hline $\begin{array}{ll}\text { H } & 250 \\
\text { H } 200\end{array}$ & $\begin{array}{l}2,150 \\
2,120\end{array}$ & $\begin{array}{l}76.2 \\
79.6\end{array}$ & $\begin{array}{l}90 \\
94\end{array}$ & $\begin{array}{l}1,460 \\
1,580\end{array}$ & $\begin{array}{l}34.8 \\
34.7\end{array}$ & $\begin{array}{l}31.9 \\
33.2\end{array}$ & $\begin{array}{l}1.48 \\
1.63\end{array}$ & $\begin{array}{l}1,640 \\
1,880\end{array}$ \\
\hline $\begin{array}{ll}N & 200 \\
N & 150\end{array}$ & $\begin{array}{l}1,740 \\
1,690\end{array}$ & $\begin{array}{l}70.5 \\
80.1\end{array}$ & $\begin{array}{l}86 \\
86\end{array}$ & $\begin{array}{l}1,020 \\
1,220\end{array}$ & $\begin{array}{l}28.4 \\
26.7\end{array}$ & $\begin{array}{l}26.6 \\
32.8\end{array}$ & $\begin{array}{l}1.59 \\
1.76\end{array}$ & $\begin{array}{l}1,200 \\
1,540\end{array}$ \\
\hline $\begin{array}{ll}\text { L } & 150 \\
\text { L } & 100\end{array}$ & $\begin{array}{l}1,210 \\
1,050\end{array}$ & $\begin{array}{l}52.3 \\
66.7\end{array}$ & $\begin{array}{l}88 \\
91\end{array}$ & $\begin{array}{l}570 \\
690\end{array}$ & $\begin{array}{l}18.1 \\
14.9\end{array}$ & $\begin{array}{l}24.3 \\
32.4\end{array}$ & $\begin{array}{l}1.52 \\
1.66\end{array}$ & $\begin{array}{l}670 \\
800\end{array}$ \\
\hline
\end{tabular}

'HPL' treatments. The decrease in the 'HPL' treatments probably was caused by competition between the tillers occurring at very high densities.

Multiplying the number of seeds per ear by the 1000-grain weight gives the seed weight per ear. This proved to be almost the same in the treatments ' $H-200$ ', ' $\mathrm{N}-150$ ' and ' $\mathrm{L}-100$ ', $54.6 \mathrm{mg}$ per ear. The seed yield per $\mathrm{m}^{2}$ in this case is completely determined by the number of ears per $\mathrm{m}^{2}$. In the treatments 'H-250', 'N-200' and 'L-150' the seed weight decreased to $47.2,42.3$ and $36.9 \mathrm{mg}$ per ear, respectively; this decrease was due to poor seed setting rather than to lower 1000 -grain weights at lower light levels.

The small differences in individual seed weights indicate that either seed setting in perennial ryegrass is little affected by light level, due to the great supply of water-soluble carbohydrates in the internodes, or that, due to adapting the number of ears to the light available during the elongation stage, the light level in the crop during the seed setting stage no longer differs between the treatments. In view of the former supposition the contents of water-soluble carbohydrates were determined.

The initial great differences in number of tillers and dry-matter weight, due to the light treatment in autumn, were found to drop sharply in early spring. Since environmental conditions in spring were the same for all three treatments, only small differences were to be expected in seed yield based on number of reproductive shoots. The shaded treatment gave a significantly lower seed yield (Table 5), despite the somewhat higher number of reproductive tillers. This was mainly due to much decreased seed setting. The correlations between seed yield and the three yield components number of reproductive tillers per $\mathrm{dm}^{2}$, number of seeds per ear, and 1000-grain weight, were $-0.34,0.75$, and 0.66 , respectively.

Table 5. Seed yield and yield components in the autumn trial (1969).

\begin{tabular}{lllll}
\hline $\begin{array}{l}\text { Treat- } \\
\text { ments }\end{array}$ & $\begin{array}{l}\text { Cleaned } \\
\text { seed } \\
(\mathrm{kg} \mathrm{ha-1)}\end{array}$ & $\begin{array}{l}\text { Number of } \\
\text { reproductive } \\
\text { tillers per } \mathrm{dm}^{2}\end{array}$ & $\begin{array}{l}1,000 \text {-seed } \\
\text { weight } \\
(\mathrm{g})\end{array}$ & $\begin{array}{l}\text { Calculated } \\
\text { number of } \\
\text { seeds per } \\
\text { ear }\end{array}$ \\
$\mathbf{H}$ & 1,269 & 31.9 & 1.76 & 22.6 \\
$\mathrm{~N}$ & 1,330 & 32.0 & 1.76 & 23.6 \\
$\mathrm{~L}$ & 1,045 & 36.5 & 1.68 & 17.0 \\
\hline
\end{tabular}



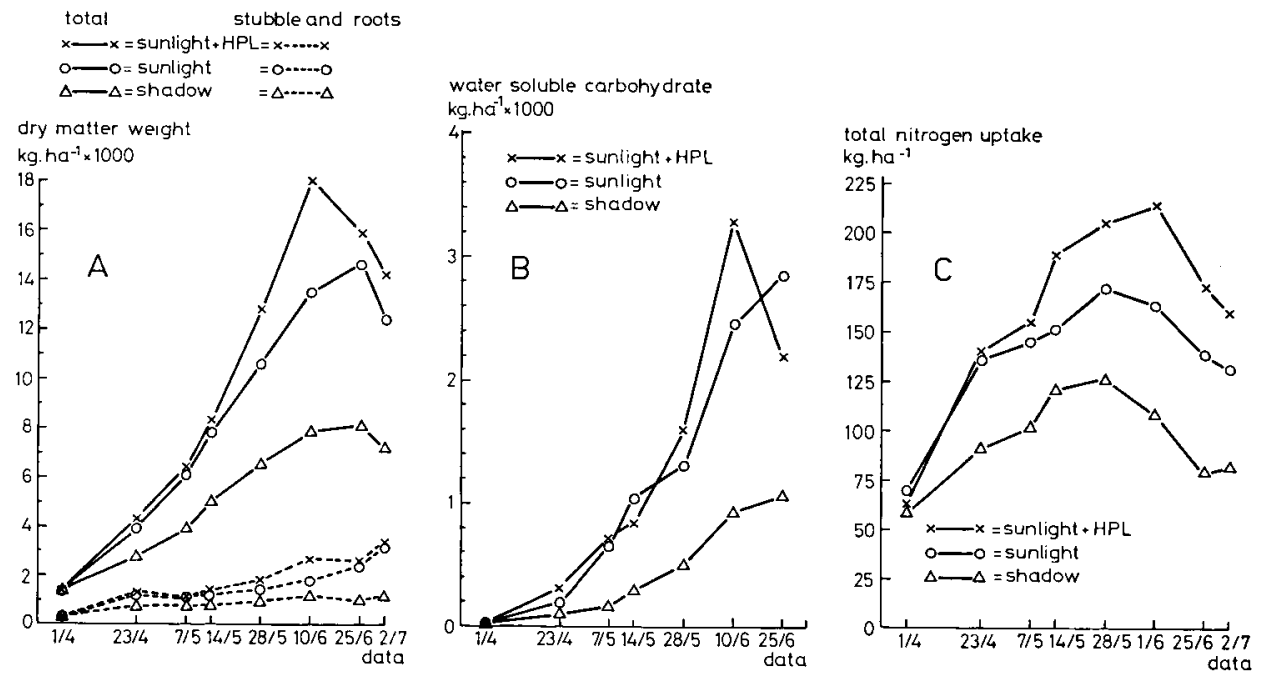

Fig. 3. Trend in dry-matter weight (A), water-soluble carbohydrates (B) and total nitrogen uptake (C) against time at three levels of light intensity.

\section{Contents of nitrogen and water-soluble carbohydrates in the shoot}

To study the influence of the carbohydrate source and that of the availability of nitrogen on seed setting, the contents of water-soluble carbohydrates and total nitrogen were determined. These analyses were carried out separately in tillers, stubbles and roots of the material available of the spring experiment.

The nitrogen content showed a linear decrease with time, in the tillers this averaged from $5.25 \%$ on 1 April to $1.10 \%$ on 25 June; in stubbles and roots there was initially a sharp decrease which continued slowly from heading. The total-nitrogen content in stubbles and roots was of the same order: on 1 April about $2.55 \%$ and on 25 June about $0.95 \%$. The slight differences in nitrogen content between the three light levels showed, that light affected the nitrogen uptake through the dry-matter production; this effect which was expected was compensated by adjusting the nitrogen fertilizer dressing to the light level. The $50 \mathrm{~kg}$ additional nitrogen per ha produced higher contents, but they had a negative effect on the seed yield instead of a positive one. The parts of the tillers harvested, at flowering had taken up nitrogen to the equivalent of about $90 \%$ of the dressing, whereas stubbles and roots, not harvested, had incorporated about $8 \%$. During maturation a considerable part of the nitrogen taken up was lost again, probably by leaching, leaf drop and microbial decomposition (Fig. 3C).

Although the nitrogen content in the shoot decreased after flowering, it increased in the ears (Table 6). Nitrogen quantity in the ears was determined by ear weight rather than by the nitrogen content. As a result nitrogen quantity in the ears and seed increased with increasing light intensity, whereas there only was a slight decrease in nitrogen content. This indicates that nitrogen availability was not limiting in seed setting.

The content of water-soluble carbohydrates gives some idea about the availability of assimilates to the growing plant parts. From the beginning of April to before maturation the content in the tillers increased almost linearly, except for a retardation during stem 
Table 6. Nitrogen content and concentration in ears and seed of spring trial (1968).

\begin{tabular}{|c|c|c|c|c|c|c|}
\hline \multirow[t]{2}{*}{ Date } & \multicolumn{2}{|c|}{$H(188 \mathrm{cal} \mathrm{cm-2} \mathrm{day-1)}$} & \multicolumn{2}{|c|}{$N(140 \mathrm{cal} \mathrm{cm-2} \mathrm{day-1)}$} & \multicolumn{2}{|c|}{ L ( 84 cal cm-2 day-1) } \\
\hline & $\% \mathrm{~N}$ & $\mathrm{~kg} \mathrm{~N} / \mathrm{ha}$ & $\% \mathrm{~N}$ & kg N/ha & $\% \mathrm{~N}$ & $\mathrm{~kg} \mathrm{~N} / \mathrm{ha}$ \\
\hline \multicolumn{7}{|l|}{ Ears } \\
\hline $\begin{array}{l}28-5 \\
10-6 \\
25-6\end{array}$ & $\begin{array}{l}1.90 \\
1.79 \\
1.70\end{array}$ & $\begin{array}{l}34.2 \\
55.8 \\
53.2\end{array}$ & $\begin{array}{l}2.05 \\
1.90 \\
1.52\end{array}$ & $\begin{array}{l}29.7 \\
41.0 \\
36.3\end{array}$ & $\begin{array}{l}2.26 \\
2.14 \\
1.84\end{array}$ & $\begin{array}{l}16.3 \\
22.3 \\
21.5\end{array}$ \\
\hline \multicolumn{7}{|c|}{ Seed ultimate harvest } \\
\hline & 2.25 & 39.5 & 2.27 & 31.1 & 2.35 & 17.2 \\
\hline
\end{tabular}

Table 7. Content of water-soluble carbohydrates in seed and straw at harvesting in the $H, N$ and $L$ treatments in the spring trial (1968).

\begin{tabular}{lccc}
\hline & H $(188 \mathrm{cal} \mathrm{cm-2}$ day-1) & N (140 cal cm-2 day-1) & N (84 cal cm-2 day-1) \\
Seed & 3.2 & 3.5 & 2.7 \\
Straw & 12.0 & 13.1 & 7.8 \\
\hline
\end{tabular}

elongation: in the additional light and sunshine treatments from 3.5 to $21.5 \%$ in the dry matter; in the shade treatment from 2.1 to $14.3 \%$ in the dry matter. At maturation a sharp drop occurred in the content, first in the additional light treatment; the other treatments were harvested before this stage.

The content in the stubbles varied considerably during the growing season. Quantitatively, however, there only was a small part of the carbohydrates in the stubbles: about $10 \%$ of that in the above-ground parts.

Total water-soluble carbohydrates in tillers and stubbles increased exponentially up to 14 days after flowering (Fig. 3B) after which it levelled or decreased. Although distribution of carbohydrates in leaf, stem and ear was not determined, a shortage of carbohydrates during flowering and the beginning of seed setting is not likely, considering the trend in the content of the entire shoot. Also during maturation the content of water-soluble carbohydrates was higher in stem plus leaf than in the seed (Table 7).

\section{Assimilating area of the crop}

The effect of light was not limited to tillering and fertility of the tillers, but also affected the morphological size of the tillers. In the spring experiment leaf length increased with lower light intensity. The result of the differences in leaf length for the leaf area per surface unit of soil was reduced by the contrasting trend in the number of earbearing tillers per $\mathrm{dm}^{2}$ (Fig. 4A). The lengths of internode (1) and ear were initially longer in the additional light treatment, probably due to a small difference in development stage; this lead was made up and even surpassed by the treatments with lower light intensity. The length differences in internodes and ears were too small to affect the size of the green leaf area (Fig. 4B en C).

To gain some idea of the light-interceptive capacity of the crop, the green areas of leaf 

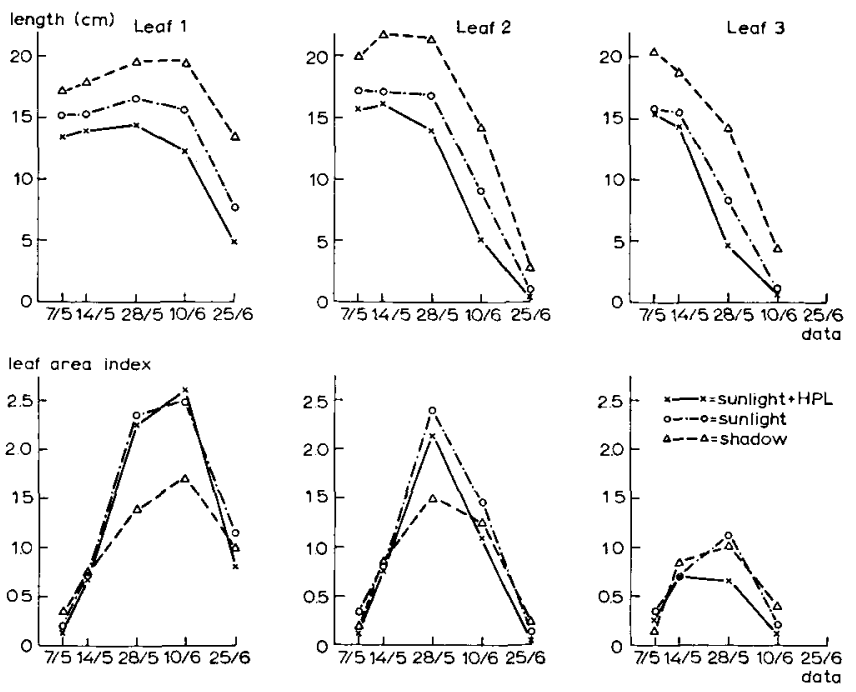

Fig. 4A. Trend in length and area index of the three top leaves from heading onwards at three light intensities.

Internode 1
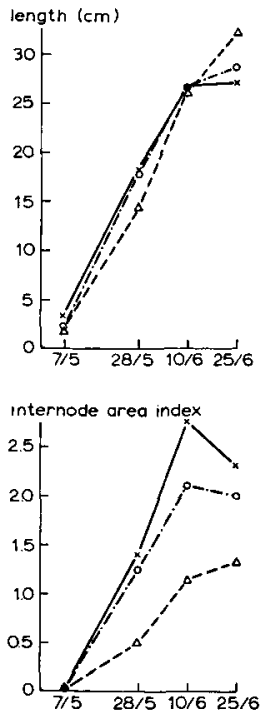

Internode 2
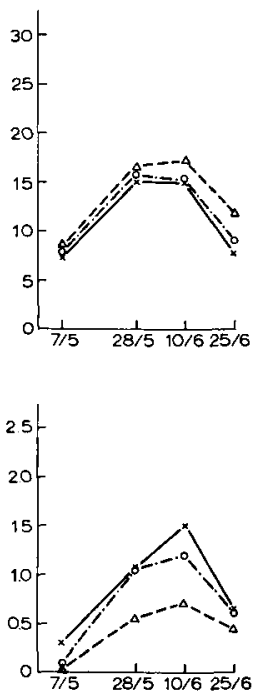

Internode 3
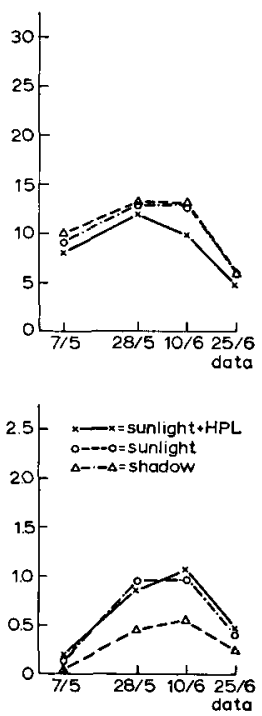

Fig. 4B. Trend in length and area index of the three top internodes from heading onwards at three light intensities.

Neth. J. agric. Sci. 20 (1972) 

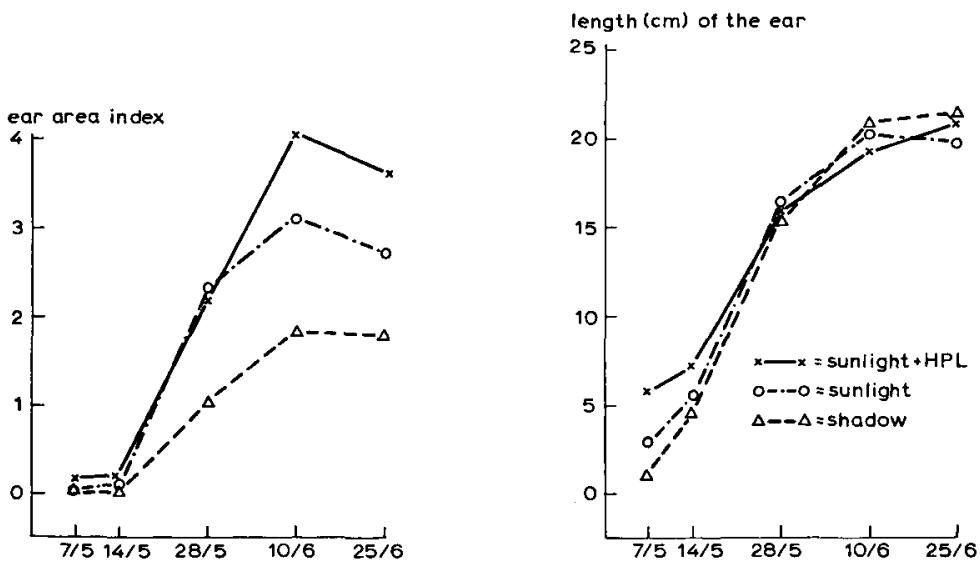

Fig. 4C. Trend in length and area index of the ear at three light intensities.

Table 8. Added green area (ha ha-1) of ear and three topmost leaves and internodes of the reproductive tillers in the spring trial (1968).

\begin{tabular}{rlclr}
\hline Date & H (188 cal cm-2 day-1) & $\mathrm{N}(140 \mathrm{cal} \mathrm{cm-2}$ day-1) & $\mathrm{L}(84 \mathrm{cal} \mathrm{cm-2}$ day-1) & Mean \\
$7-5$ & 2.8 & 1.2 & 0.7 & 1.6 \\
$14-5$ & 4.2 & 3.7 & 3.4 & 3.8 \\
$28-5$ & 10.9 & 11.1 & 6.6 & 9.5 \\
$10-6$ & 13.2 & 11.6 & 7.7 & 10.8 \\
$25-6$ & 7.9 & 7.0 & 5.2 & 6.7 \\
\hline
\end{tabular}

1 through 3, internodes 1 through 3 and ear have been added (Table 8). Leaf area contri. buted most in the period of heading until flowering, internodes and ears contributing most during and after flowering. Since the area indices were very high, the green area will have been rather too high than too low for optimum assimilate production. Possibly, the respiratory losses are rather high at such high densities, although the contents of water-soluble carbohydrates do not indicate this.

\section{Discussion}

The determining factors in the seed yield of perennial ryegrass are: number of ears per unit area; number of spikelets per ear; percentage of seed setting; and individual seed weight. The ultimate value of these components is the result of cumulative effects of cultivation measures and habitat factors during growth and development of the individual plants to a seed producing crop. A typical characteristic of the crop situation in general is that in certain growth stages there is a considerable competition for light; the plants can adapt themselves to a considerable degree with their compensative capacity.

The effect of additional light on dry-matter production in autumn as well as in spring 
showed that in certain periods there was considerable light deficiency in the crop. During vegetative growth light intensity had an appreciable effect on the formation of new tillers (Table 1) and at the time of changing from the vegetative to the reproductive stage a highly regulating activity on the ear formation of the tillers present (Fig. 1). The number of ear-bearing tillers in spring experiment (1968) was highly correlated $(r=0.95)$ to the ultimate seed yield; which corresponds to van der Meer's findings (1969), he obtained a wide variation in reproductive tillers with nitrogen dressings in 3 variaties, the seed yield being positively correlated. An increase in the number of reproductive tillers need not always mean a higher seed yield, as demonstrated in the autumn experiment (1969). In this experiment the thin stand obtained in autumn by shading, as a result of 'rejuvenation' of the crop, was completely compensated by considerable tillering in spring and even resulted in a somewhat higher reproductive tiller number. Due to the decreased fertility of the late formed reproductive tillers, this resulted in an even lower seed yield and in a negative correlation $(\mathrm{r}=-0.34)$ with the number of ears.

The great differences in seed yield from year to year, which are a regularly occurring feature in practical grass seed growing, are most likely due to the wide variation in the number of seeds per ear. Table 4 shows that due to lodging the number of seeds per ear may decrease sharply, when the nitrogen application has been too high.

Lewis's findings (1970) clearly showed that by selection for fertility of the tillers, the number of spikelets per ear, the number of florets per spikelet as well as seed setting will permit a considerable increase in seed yield, while retaining the good characteristic for adequate nutritive value.

In perennial ryegrass the effect of light intensity was found to be not critical within a wide range, but it did bring about a quantitative effect on the components determining the seed yield. In this experiment, especially the number of reproductive tillers per $\mathrm{m}^{2}$. To establish the actual effect on seed setting and individual seed weight, the light intensity should be varied within specific growth stages, instead of continuously throughout the growing season.

Ryle (1967) stated that decreased light intensity retards or inhibits ear initiation, decreases the number of fertile tillers and reduces the size of ears. Except for the ear size, these findings correspond with those in this experiment; ear size, however, was not smaller, but even somewhat larger.

These effects will have been caused primarily by the availability of assimilates to the actively growing plant parts. Ryle's (1970) ${ }^{14} \mathrm{C}$ trials show that the distribution of assimilates in perennial ryegrass is basically similar to the pattern in wheat; however, in perennial ryegrass, in the vegetative stage the tillers and in the reproductive stage the internodes are a relatively more important sink than in wheat. This implies that much light in the vegetative stage will stimulate tillering; which is confirmed by the results of the present experiments. The relatively great strength of the stem indicates a retarded or blocked translocation to the seed in the ear. This may be related to the perennity of perennial ryegrass, requiring a large supply of reserves in the vegetative organs of the plant for good persistency. The high carbohydrate content in the internodes, however, under adverse conditions (lodging, high temperature) may cause high respiratory losses, which will occur to a much less extent in the seed due to sugars being converted to starch.

Table 8 shows that for effective light utilization there is an excessively great green area in a grass seed crop. A culm length of $95 \mathrm{~cm}$ is prone to lodging and requires many assimilates for its construction and for reserves. In view of these aspects, it might be favourable to seed production, if selection was applied for shortness and firmness of the reproductive shoots. 


\section{Acknowledgments}

Thanks are due to Prof. Ir M. L. 't Hart and Ir L. J. P. Kupers for their interest and encouragement.

The translation in English was done by Miss A. H. van Rossem.

\section{References}

Anslow, R. C., 1962. The seed production of some herbage species in temperate regions. Mimeographed. Publ. No 1. G.R.I., Hurley.

Anslow, R. C., 1963. Seed formation in perennial ryegrass. I. Anther exsertion and seed set. $J . B r$. Grassld Soc. 18: 90-96.

Brougham, R. W., 1958. Interception of light by the foliage of pure and mixed stands of pasture plants. Aust. J. agric. Res. 9: 39-52.

Cooper, J. P., 1960. The use of controlled life-cyclus in the forage grasses and legumes. Herb. Abstr. 30: 71-79.

Donald, C. M. \& J. N. Black, 1958. The significance of leaf area in pasture growth. Herb. Abstr. 28: $1-6$.

Evans, L. T. \& I. F. Wardlaw, 1964. Inflorescence initiation in Lolium temulentum L. IV. Translocation of the foral stimulans in relation to that of assimilates. Aust. J. biol. Sci. 17: 1-9.

Evers, A. \&. A. Sonneveld, 1956 Graszaadteeltproeven IV. Meded. C.I.L.O. Wageningen, No. 25.

Hryncewicz, Z., 1967. De dynamisme de développement des variétés de raygrass anglais (Lolium perenne L.). Rech. agron. Suisse 6: $227-245$.

Kleinendorst, A. \& A. Sonneveld, 1965. Influence of the vernalisation period and light intensity on shooting and composition of the inflorescence of perennial ryegrass (Lolium perenne L.). Jaarb. Inst. biol. scheik. Onderz. Landb.Gewass. 1965: 49-57.

Koblet, R., J. Lehman \& J. Nösberger, 1969. Ueber die Bestockung und ihre Auswirkungen auf die Ertragsbildung bei Futtergräsern. Schweiz. land. Forsch. 8: 80-108.

Langer, R. H. M. \& D. A. Lambert, 1959. Earbearing capacity of tillers arising at different times in herbage grasses grown for seed. J. Br. Grassld Soc. 14: 137-140.

Langer, R. H. M., 1966. Mineral nutrition of grasses and cereals. The growth of cereals and grasses, Milthorpe \& Ivins, 1966, 213-227.

Lewis, J., 1970. Jubilee Report of the Welsh Plant Breeding Station, 1919-1969, Aberystwyth, p. 92.

Meer, H. G. van der, 1969. De invloed van stikstof op de snelheid en mate van doorschieten van 3 Engelse raaigrassen en de betekenis daarvan voor enkele aspecten van de voederwinning en de zaadteelt. Proefverslag Graslandcultuur, Afdeling Landbouwplantenteelt en Graslandcultuur, Landbouwhogeschool, Wageningen: $21-24$.

Roberts, H. M., 1965. The seed productivity of perennial rye-grass varieties. J. agric. Sci. 66: $225-232$.

Ryle, G. J. A., 1961. Effects of light intensity on reproduction in S48 timothy. Nature, Lond. 191: 196.

Ryle, G. J. A., 1964. The influence of date of origine of the shoot and level of nitrogen on ear size in three perennial grasses. Ann. appl. Biol. 53: 311-323.

Ryle, G. J. A., 1967. Effects of shading on inflorescence size and development in temperate perennial grasses. Ann. appl. Biol. 59: 297-308.

Ryle, G. J. A., 1970. Distribution pattern of assimilated ${ }^{14} \mathrm{C}$ in vegetative and reproductive shoots of Lolium perenne and Lolium temulentum. Ann. appl. Biol. 66: 155-167.

Schöberlein, W., 1966. Untersuchungen über die kausalen Zusammenhänge zwischen vegetativer Sprossenentwicklung im Herbst und generativer Triebbildung im Frühjahr bei Gräsern. 4. Grünlandsymp. (Leipzig, 1966): 105-127. 